\title{
Emotional Intelligence, Personality, and Its Impact on Leadership Capability; Subsequently on the Effectiveness of Decision Making
}

\section{Ahmad Fauzan, Said Musnadi, Sulaiman}

To Link this Article: http://dx.doi.org/10.6007/IJARBSS/v11-i3/8973

DOI:10.6007/IJARBSS/v11-i3/8973

Received: 21 January 2021, Revised: 23 February 2021, Accepted: 08 March 2021

Published Online: 17 March 2021

In-Text Citation: (Fauzan et al., 2021)

To Cite this Article: Fauzan, A., Musnadi, S., \& Sulaiman. (2021). Emotional Intelligence, Personality, and Its Impact on Leadership Capability; Subsequently on the Effectiveness of Decision Making. International Journal of Academic Research in Business and Social Sciences, 11(3), 574-590.

\section{Copyright: (c) 2021 The Author(s)}

Published by Human Resource Management Academic Research Society (www.hrmars.com)

This article is published under the Creative Commons Attribution (CC BY 4.0) license. Anyone may reproduce, distribute, translate and create derivative works of this article (for both commercial and non-commercial purposes), subject to full attribution to the original publication and authors. The full terms of this license may be seen

at: http://creativecommons.org/licences/by/4.0/legalcode

Vol. 11, No. 3, 2021, Pg. 574 - 590

Full Terms \& Conditions of access and use can be found at http://hrmars.com/index.php/pages/detail/publication-ethics 


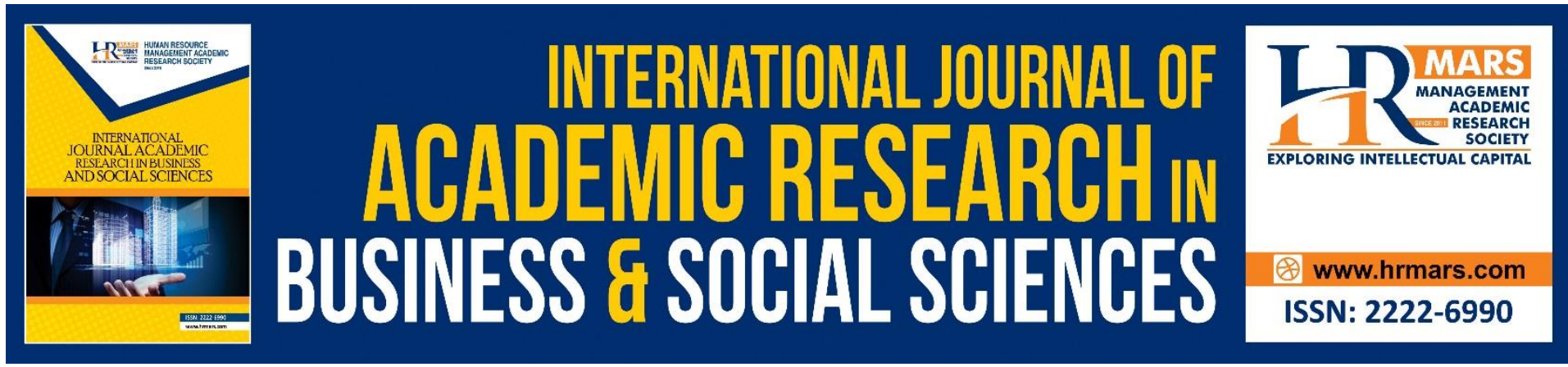

\title{
Emotional Intelligence, Personality, and Its Impact on Leadership Capability; Subsequently on the Effectiveness of Decision Making
}

\author{
Ahmad Fauzan ${ }^{1}$, Said Musnadi², Sulaiman ${ }^{3}$ \\ 1) Magister of Management Post-Graduate Study of Syiah Kuala University Banda Aceh, 2,3) \\ Faculty of Economic and Business, University of Syiah Kuala \\ Email: elman_ali@unsyiah.ac.id
}

\begin{abstract}
The purpose of this study is to assess the effect of emotional intelligence and personality on effectiveness of decision making and to analyze the existence of capability leadership as a mediating variable in the functional relationship between these variables. The study utilizes a purposive random sampling involving of 200 employees as respondents at PT. Bank Aceh Syariah in Aceh Province. Data is collected by a questionnaire survey and analyzed by Structural Equation Modeling (SEM) and Hierarchical Regression Model (HRM). The study finds that emotional intelligence effects positively and significantly on leadership capability, it's subsequently of effectiveness of decision making. However, personality does not effect on leadership capability; oppositely, it does on effectiveness of decision making. The existence of the capability leadership mediates the effect of emotional intelligence on effectiveness of decision making. On the other hand, the capability leadership does not mediate the effect of personality on capability leadership.
\end{abstract}

Keywords: Effectiveness of Decision Making, Leadership Capability, Emotional Intelligence, Personality.

\section{Introduction}

There have been many previous studies that explain the factors that affect capability leadership. These factors include psychological empowerment, competence and meaningful work (Degago, 2014); organizational culture (Uddin et al., 2013); direct compensation (Ahmed \& Ahmed, 2014); emotional intelligence (Chong \& Van, 2013; \& Shahzadi et al., 2014); job satisfaction (Chong \& Van, 2013; Fadlallh, 2014; Luthans, 2015; Robbins, 2012; and Chong \& Dung, 2013); work environment (Srivastava, 2008); and leadership (Bello, 2014), and transformational leadership (Ali and Tang, 2016; and Mohiuddin, 2017).

In further research, there are personality (Robbins, 2012; Situmeang, 2017; Syamsidar \& Hasyim, 2018) which can also affect capability leadership and performance.

However, there is a little study that pay attention to this factor (personality), especially if it acts as a mediator effecting on leadership capability; its subsequently on effectiveness of decision making. The role of leadership capability to influence on effectiveness of decision making is supported by a number of studies. Research conducted by Madi, S. A. et al (2018) 
find that the capability leadership intervenes in the influence of effectiveness of decision making. On a macro scale, the capability leadership also mediate the effect of emotional intelligence (Al-Azzam, 2015; and Ejimabo, 2015) and personality (Hou, 2014) on effectiveness of decision making. Hess and Bacigalupo (2013) research also proves that emotional intelligence influence on decision making. On the other hand, the result of Rehman and Scholar (2011) study indicates that emotional intelligence effects on capability of leadership. Moreover, Knight (2014) justifies that personality of leaders can enhance the ability of them to make better decision due to it increase their capability of leadership; for example, it may occur at PT. Bank Aceh Syariah as a banking business institution owned by Aceh Province Government.

PT. Bank Aceh Syariah has structural and non-structural staffs that are distributed in as many as 27 of branch office at Aceh District. In terms of structural staffs, they are who already have a letter of the leadership position. Meanwhile, non-structural staffs are employees who already have a Decree and information on the rights and obligations of employees; however, they are not in leadership level position.

The effectiveness of decision making can be seen from their leadership capability, personality and emotional intelligence. it can be made by every personnel in the company, not only leaders, but also it can be done by ordinary employees who one day can play a role as leaders. Therefore, the leadership capabilities that can be demonstrated by each personnel in an organization and how it affects the decision-making to complete their respective work is an interesting issue to discuss. Because the better or more effective the decisions taken in the context of problem solving, the easier the existing problems will be solved which will have an impact on increasing employee productivity (Musnadi, S., et al 2018).

At a theoretical level, the effectiveness of decision making is closely related to leadership. Leadership is a process between relationships or interactions between leaders, followers and situations. Because leadership involves other people, decision making is the most important part of the leadership function itself (Djatmiko, 2005). Thus, leadership capability is essential factor to be considered in order to get a business successful.

However, due to very little attention from the previous studies having pay attention for this matter (capability of leadership) as a mediator factor; therefore, it seems still hazy for academics and practitioners that appears the gab of understanding.

Based on the above viewpoint, it is necessary to conduct further research to eliminate the gap due to the insufficient understanding. Thus, objective of this study is:

- To investigate relationships between emotional intelligence, personality and leadership capability

- To investigate relationships between emotional intelligence, personality and effectiveness of decision making

- To investigate the role of leadership capability as mediator among the relationship of emotional intelligence, personality and effectiveness of decision making.

This study may result a contribution to academics and practitioners whereas the role of leadership capability as a mediator between the relationships.

\section{Literature Review \\ Effectiveness of Decision Making}

Effectiveness of decision making is the action taken by management for solving a problem in detail and on target and not causing new problems in order business activities run 
smoothly (Al-Tarawneh, 2012). According to Tarawneh (2012), decisions are made at every level of management to ensure business goals achieved. Furthermore, the decisions make up one of the core functional values that every organization adopts and implements to ensure optimal growth and drivability in terms of the services and/or products offered that it reflects its effectiveness.

Indicators of effective decision making according to Syamsi (2010) can be measured by: achieving the objectives of the impact of decision making; determination of correct alternatives as part of decision making; availability of adequate information that has been known in advance, and; objectives achieved are quantified (measurable).

\section{Leadership Capability}

According to Rahim (2015), leadership capability is the ability of a leader in managing the organization and the resources owned by the organization. Leadership capability can be seen through the leader's ability, commitment, and consistency.

Sulistiyani (2012) argues that leadership can run smoothly and successfully in initiating groups that need to be supported by the capabilities of the leader.

Furthermore, Maulida and Yunus (2012) also explain that capability is the psychological mental condition of a leader that reflects the full stability and ability and responsibility to bear all the consequences of office and leadership.

Bowles \& Lanyon (2016) indicates that the capability of a leader can be measured as a leader who has: orientation and vision for the future; developing and empowering others; inspiring and (emotionally) engaging people; changing and innovation; integrity and compliance with standards; result orientation; self-awareness and courage; critical thinking; collaboration and influencing; ethical and cultural awareness; communication and relationship management, and; technical mastery.

\section{Emotional Intelligence}

Emotional intelligence is skills to regulate emotions that provide the ability to balance emotions in order to maximize long-term life happiness (Thaib, 2013). Emotional intelligence plays a very important role for someone because humans are emotional creatures. A person who makes dayly decisions without being based upon logically action due to he/she is carried away by feelings or emotions (Mahdani and Adam, 2017). Additionally, if leaders who have low emotional intelligence will be swayed with uncertain feelings, it will be difficult to make quick decisions (Yantiek, 2014).

Labbaf (2011: 537) reveals indicators of emotional intelligence, namely: a person with high self-awareness will be able to understand strengths, weaknesses, values and selfmotives; a person with high self-awareness will be able to think clearly before acting; the ability to control oneself means having high emotional intelligence because to control oneself requires knowledge and abilities; someone with high self-motivation always has reasons so that it provides encouragement to always improve performance; someone with high selfmotivation has a mental readiness to make sacrifices for the achievement of organizational goals; someone with high self-motivation is able to control their own emotions and use them to improve their chances of success; understand situations faced by other people; experiencing the other person's emotions; ability to manage relationships with other people, and; ability to network with other people. 


\section{Personality}

Personality is basically a dynamic arrangement hidden in a person which is a system that will create a characteristic arrangement of a person's behavior, thoughts and feelings (Robbins, 2012). This means that a person with personality has full awareness and acceptance of themselves. They alone are responsible for what makes up their life, for everything they say, do, feel or think. Furthermore, Husaini et al (2017) explain that personality is seen as a behavior motive and system. Personality includes concepts based upon circumstances, processes and psychological structures that lead to behavior (Guay et al., 2016).

Related to personality's indicators, Robbins (2012) refers to the Jackson Personality Inventory (JPI) which is a tool for measuring personality. Jackson Personality Inventory (JPI) consists of 7 indicators as follows: (1) The complexity of the level of knowledge; (2) Interest in learning something new; (3) Innovative; (4) Tolerance; (5) Empathy; (6) Hospitality, and; (7) Self-confidence.

The following research frameworks are developed that can illustrate the effect of emotional intelligence and personality on capability leadership, in which educational level acts as moderating variable influencing.

\section{Effect of emotional intelligence on effectiveness of decision making}

Hess \& Bacigalupo (2013) in their research explained that emotional intelligence can be practically applied to improve decision making for both individuals and groups. This practical approach is designed to instruct and assist decision makers in the use of emotional intelligence skills to improve decision making. The findings of Hess and Bacigalupo (2013) justify that organizations and individuals can benefit from the development and utilization of behaviors associated with emotional intelligence. The practical application of emotional intelligence skills can improve individual and group decisions and outcomes.

Based on the description above, the following hypothesis can be developed:

$\mathrm{Ha}_{1}$ : There is an influence of Emotional Intelligence on the Effectiveness of Decision Making at PT. Bank Aceh Syariah.

\section{Effect of personality on effectiveness of decision making}

Neuert and Hoeckel (2013) in their research found that there is an effect of personality trait on decision making by leaders. As decision-making behavior has become the focus of both scientific and professional positions, there appears to be a discrepancy as to whether rational or intuitive decision making leads to effective outcomes. Therefore, personality really determines the quality and effectiveness of decision making.

Furthermore, Neuert and Hoeckel (2013) conducted a study on how personality characteristics can influence the decision making process. The result was that there was a positive and significant personality effect on effective decision making.

According to the above point of view, it can be derived hypothesis as follows: $\mathrm{Ha}_{2}$ : Personality has a positive influence on effectiveness of decision making.

\section{Effect of Emotional Intelligence on Leadership Capabilities}

Emotional intelligence is how a person's relationship and communication with others in order to obtain a harmony of mutually beneficial relationships (mutual advantage) (Palmer et al., 2001). A person who can optimally express his work strength to achieve optimal results is when someone and his relationship are able to be woven in a nice job packaging. 
Cavazotte et al. (2012) stated that as long as this emotional relationship can be established "beautifully" it will produce a beautiful relationship as well. Whether the relationship between the feelings of the leader and the feelings of subordinates, etc. depends on the type of working relationship, which will be able to produce good performance. Likewise, if the relationship between feelings is not intertwined with "nice", it will result in low performance.

It is also justified by Gewertz (2006) in his research entitled Emotional intelligence: impact on leadership capabilities. Examining the effect of emotional intelligence on leadership capabilities in the health industry found a significant influence between these two variables.

Based upon the point of view above, hypothesis can be proposed as follows:

$\mathrm{Ha}_{3}$ : Emotional intelligence has a positive influence on leadership capability.

\section{Effect of Personality on Leadership Capabilities}

Conger (2004) in his research revealed that leadership capability can be developed by personality factors. Conger (2004) presents his opinion on the views of leadership development interventions notifying many factors that so far can shape the extent to which an individual who has good capabilities becomes a leader. These include genetic predisposition, family environmental personality, school experience, difficulties, work experience, authority figures, organizational incentives, and acquired training. The author argues that leaders are born and made, and believes that the foundation for leadership qualities is confidence, achievement drive, communication skills, and interpersonal competence. Thus, the better, the better personality is, the better leadership capability.

The description above can produce the following hypothesis:

$\mathrm{Ha}_{4}$ : Personality has a positive influence on leadership capabilities

\section{Effect of leadership capability on effectiveness of decision making}

Madi, et al (2018) in his research found that there was an influence of leadership capability on decision-making effectiveness. The purpose of this research is to determine how dominant leadership and its influence on decision making. The finding is that there is a direct correlation between dominant leadership capabilities and the quality of decision makers. There is no difference between the samples according to gender variables in their perceptions of dominant leadership patterns and levels of decision maker participation. Thus, at all levels of leadership, Madi, et al. (2018) argued that if the leader has good capabilities, the decisions made will be more effective. In other words, the better the leadership capabilities is, the more effective the decision making.

Based on the above premise, the following hypotheses can be proposed:

$\mathrm{Ha}_{5}$ : Leadership capability has a positive effect on the effectiveness of decision making

The indirect effect of emotional intelligence on the effectiveness of decision making through leadership capability

Research conducted by Al-Azzam (2015) proved that there is a direct and significant influence between emotional intelligence on the effectiveness of decision making. Then research conducted by Antonakis, et al. (2009) revealed that emotional intelligence had a significant influence on leadership capabilities.

Furthermore, other researchers conducted by Ejimabo (2015) reported that the influence of leadership capabilities on the effectiveness of decision making. From the three research results, it can be concluded that the role of leadership capabilities as a mediator 
between the direct influence of emotional intelligence on the effectiveness of decision making. This means that emotional intelligence can form leadership capacity first, then it will have an impact on the effectiveness of decision making.

Referring to the view above, the following hypothesis can be proposed:

$\mathrm{Ha}_{6}$ : There is an indirect effect of emotional intelligence on the effectiveness of decision making through leadership capabilities

The indirect effect of personality on the effectiveness of decision making through leadership capability

The effect of personality on capability leadership is also inseparable from the effectiveness of decision making concerned. Although personality is intended to improve capability of leadership at work, the effectiveness of decision making in realizing the objectives is highly dependent on their capability. The capability leadership is an internal employee factor that contributes to work ability, attitudes at work and ultimately also affects the achievement of their work results (e i. effectiveness of decision making).

The role of the capability leadership to mediate the effect of personality on effectiveness of decision making has been supported by a number of previous researchers. Research by Kaiser and Hogan (2011) on the effect of personality on capability leadership proves that a good employee's personality affects his capability to lead. Ojimabo (2015) discover that the capability leadership effect on effectiveness of decision making. Other studies conducted by Hou and Liu (2014) also conclude that the capability leadership impact on effectiveness of decision making.

Therefore, it is based upon the above point of view, it conclude personality may also influence effectiveness of decision making through leadership capability. Thus, next hypothesis can be proposed as follows:

$\mathrm{H}_{7}$ : The capability leadership moderates the effect of personality on capability leadership.

\section{Theoretical Framework of Study}

The relationship between endogenous variables and exogenous variables and the existence of leadership capability as a mediator in human resource studies, is not only supported by a theoretical basis, but also strengthened by previous studies as previously explained. Therefore, the paradigm or relationship between concepts (variables) in this study can be described in the following figure:

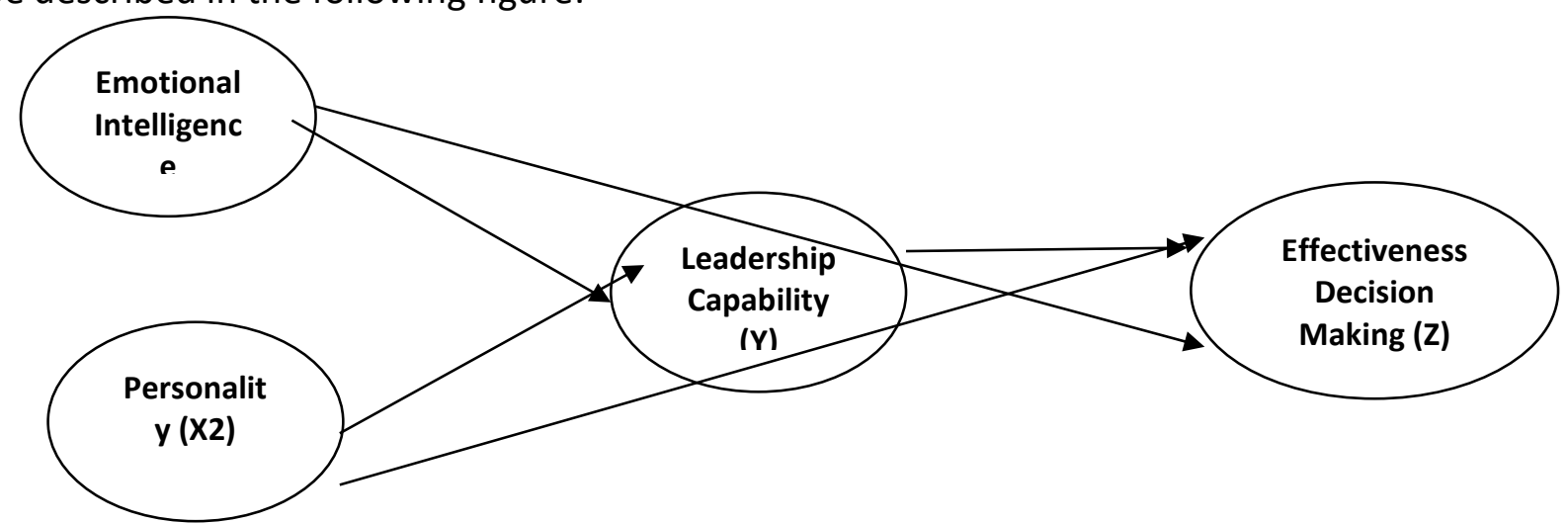

Figure 1. Theoretical Framework of This Study 


\section{Research Method}

\section{Research location, population and sample}

This study is conducted at PT. Bank Aceh Syari'ah in Aceh's Province. As the subject of this research are employees working at the bank. The population in this study is all employees, who are 1553 of them spread across 27 branch offices. Hair et al. (2011) explains that the appropriate sample size for SEM is between 100-200 samples or 5 times the number of indicators (31 indicators) contained in the research model. Thus, the minimum number of respondents who are representative based on the above opinion is 155 samples. According to the opinion of Hair et al. (2011), this research use a sample size of 200 employees, where the number is greater than the minimum number that must be met..

\section{Data Analysis}

The object of research is related to the relationship between the performance of college employees with emotional intelligence, personality and leadership capability. In this case, the capability leadership is positioned as a mediating variable between emotional intelligence, personality and effectiveness of decision making. Primary data is utilized by distributing questionnaire that is circulated to selected employees. Furthermore, the data are analyzed using statistical tools of structural equation modeling (SEM) as suggested by Hair et al. (2013), and Hierarchical Regression Model (HRM) to analyze indirect effect based upon Baron and Kenny's (1986) viewpoint.

\section{Research Finding and Discussion}

\section{Structural Equation Modeling (SEM): Step-One Approach with Measurement Model}

According to the study conceptual framework, the endogenous variable in the study is capability leadership and effectiveness of decision making. Furthermore, the exogenous variables consist of emotional intelligence and personality. According to Hair et al. (2013), the measure of goodness of fit in SEM uses several measurements consisting of $X^{2}$ or chi-square statistics, GFI (Goodness of Fit Index), AGFI (Adjusted Goodness of Fit Index), CMIN / DF, namely minimum sample discrepancy function divided by degree of freedom, TLI (Tucker Lewis Index) and CFI (Comparative Fit Index) based upon being suggested by Hair et al. (2013). The final results of the measurement model can be seen in the following figure: 


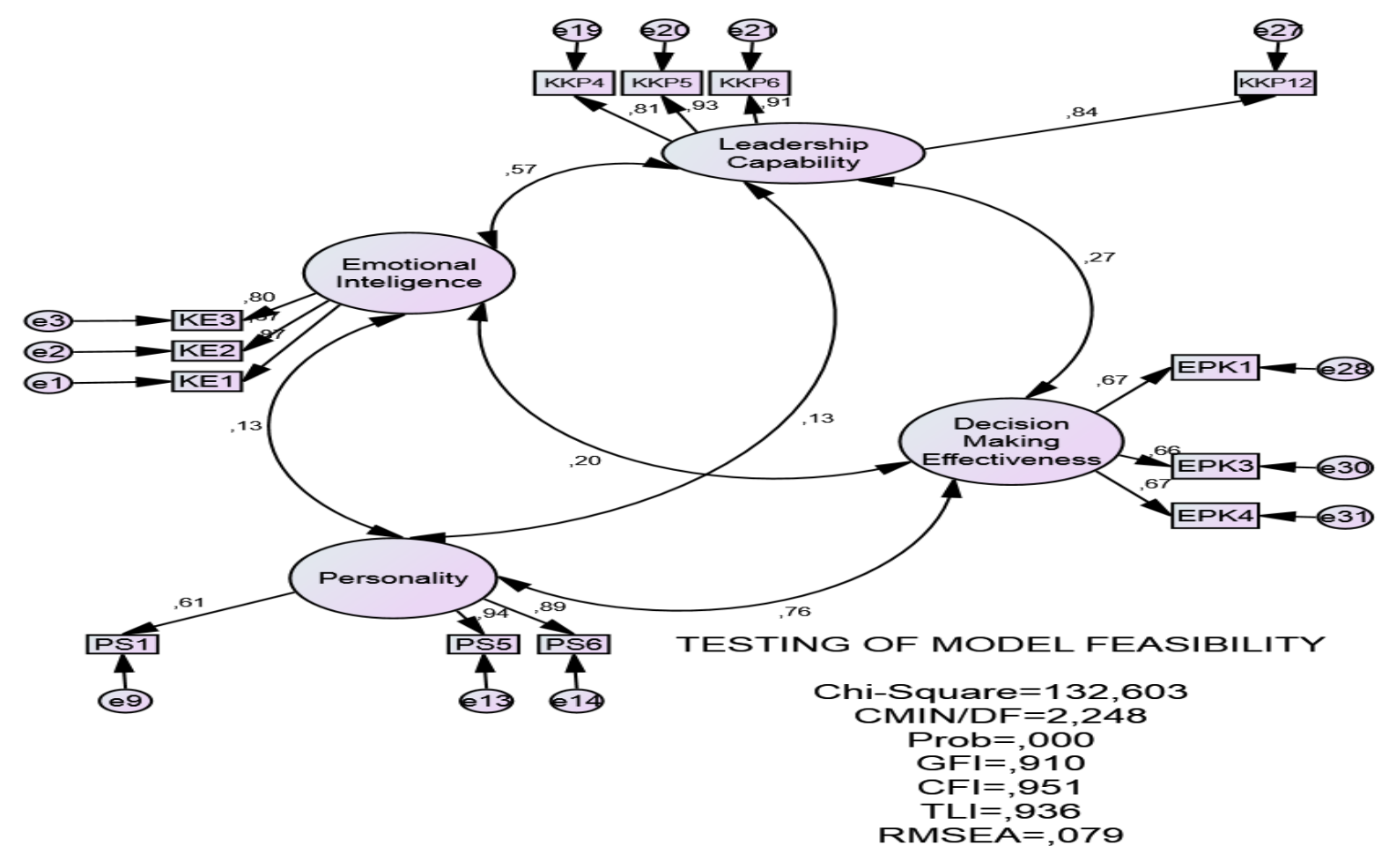

Figure 2. Measurement Model

The results of the analysis above indicate that the value of Chi-square the $X^{2}$ value counted at 132.603 at $d f=59$. This means that the calculated $X^{2}$ statistical value has met the predetermined criteria, so that the model is declared goodness fit. The probability or $p$-value of the measurement model results in this second stage of 0.079 has also met the predetermined criteria, which is above 0.05 . This means that it is seen from the $p$-value, the results of the measurement model have met the goodness of fit index requirements. Furthermore, based on the criteria, the GFI value has also met the requirements, which is 0.910 , which is greater than the required value of 0.90 . Likewise, the CFI value of 0.951 and the TLI value of 0.936 are also greater than 0.90 (Hair et al., 2013).

Based on the description above, it is clear that the results of measurement model testing indicate that all the criteria have been met; therefore, the next step can be continued to the full structural equation model.

\section{Structural Equation Modeling (SEM): Step-Two Approach with Full-SEM}

This approach emphasizes on testing the theoretical model or framework of this research (see Figure 1 and the hypotheses previously described).

The final output shows that the structural equation model is fit and satisfactory for sample data with $x^{2}=132.603$ at $\mathrm{p}<0.001 ; \mathrm{GFI}=0.910, \mathrm{AGFI}=0.936, \mathrm{CFI}=0.951$ and $\mathrm{TLI}=$ 0.936, RMSEA $=0.079$. This output also shows that all loading factors in the model are significant at $p<.001$. As explained earlier, goodness-of-fit statistics (i.e. $x^{2}$ ) must display $p>$ .05 to get a good and fit model.

A clearer picture of this structural equation model can be displayed as follows: 


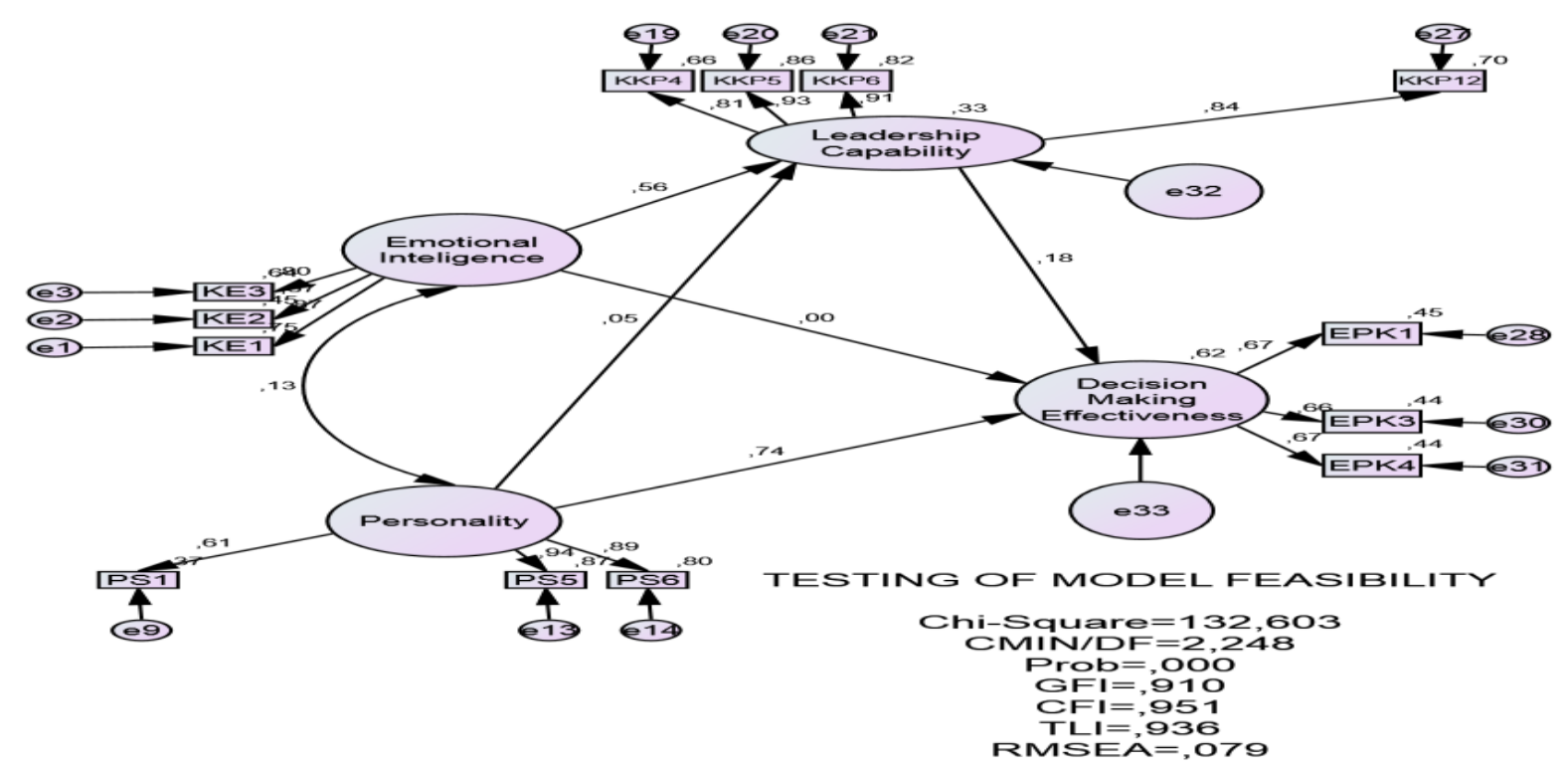

Figure 3. Full Structure Equation Modeling

The picture above not only shows the value of the path coefficient (Standardized Regression Weights) of each exogenous latent variable against the endogenous latent variable, but also shows the loading factor value of each indicator (manifest variable) on the latent variable.

\section{Direct Hypothesis Testing}

The next step is testing the hypothesis based upon the critical ratio (CR) and the probability $(P)$. The results of processing must be a value that is referenced, namely $C R>1.96$ with $\mathrm{P}<0.05$.

Furthermore, the path coefficient of each exogenous construct (emotional intelligence and personality) to the endogenous construct (capability leadership) is shown in the table below.

Table 1: Relationship among Constructions

\begin{tabular}{|c|c|c|c|c|c|c|c|}
\hline & & & $\begin{array}{r}\text { Estimat } \\
\mathrm{e}\end{array}$ & S.E. & C.R. & $P$ & Label \\
\hline Leadership capability & $<---$ & $\begin{array}{l}\text { Emotional } \\
\text { intelligence }\end{array}$ & ,430 & $\begin{array}{r}, 06 \\
5\end{array}$ & 6,623 & $* * *$ & par_10 \\
\hline Leadership capability & $<---$ & Personality & ,056 & $\begin{array}{r}, 07 \\
0\end{array}$ & ,803 & ,422 & par_11 \\
\hline $\begin{array}{l}\text { Decision making } \\
\text { effectiveness }\end{array}$ & $<---$ & $\begin{array}{l}\text { Leadership } \\
\text { capability }\end{array}$ & 197 & $\begin{array}{r}, 09 \\
9\end{array}$ & 1,997 & 046 & par_12 \\
\hline $\begin{array}{l}\text { Decision making } \\
\text { effectiveness }\end{array}$ & $<---$ & Personality & ,869 & $\begin{array}{r}, 14 \\
0\end{array}$ & 6,206 & $* * *$ & par_13 \\
\hline $\begin{array}{l}\text { Decision making } \\
\text { effectiveness }\end{array}$ & $<---$ & $\begin{array}{l}\text { Emotional } \\
\text { intelligence }\end{array}$ & ,003 & $\begin{array}{r}, 07 \\
8\end{array}$ & 042 & 967 & par_14 \\
\hline
\end{tabular}

Source: Output of Data Analysis (2020) 
The results from the above table show that the criteria value of C.R. and the $P$ value that meets the requirements consisting of the variable of emotional intelligence with capability leadership (C.R. $=6.623$ and $P=0.000$ ), leadership capability with effectiveness of decision making $(C . R=1.997$ and $P=.046)$, and personality with effectiveness of decision making (C.R. $=6.206$ and $P=0.000)$.

Emotional intelligence has a positive and significant effect on leadership capability indicated by the estimated coefficient value of .430 and the $p$-value of $0.000(<0.05)$. The higher the emotional intelligence, the higher the leadership capability will be. Conversely, a decrease in emotional intelligence can significantly reduce leadership capability. The existence of a positive and significant effect of emotional intelligence on leadership capability indicates that the drive in them to do work has an impact on the work they get. So that when their emotional intelligence increases, the results of their capability will also increase. Conversely, a decrease in emotional intelligence has a negative impact on the capability they get. This finding supports the hypothesis $1\left(\mathrm{H}_{1}\right)$; in other words, $\mathrm{H}_{1}$ cannot be rejected.

This finding support the research results of Hess \& Bacigalupo (2013), and Ejimabo (2015) which conclude that there is a positive and significant relationship between emotional intelligence and capability leadership. The better the emotional intelligence of an employee, the better the leadership capability concerned. These results are also consistent with the findings of Rehman \& Scholar (2011), and Hou et al. (2014) who also find that emotional intelligence has a positive and significant effect on leadership capability.

Personality also has a positive and significant impact on the decision making effectiveness indicated by the estimated coefficient of .869 with a p-value of $0.000(<0.05)$. Increasing the intensity of personality has an impact on improving decision making effectiveness. This is because personality is basically intended to ensure the implementation of decision making properly. When there are errors in decision, personality has the role of evaluating and correcting these errors so that it can be corrected.

The result presents that there is an existence of a positive and significant effect of personality on decision making effectiveness, whereas the finding indicate to support hypothesis $2\left(\mathrm{H}_{2}\right)$. This is consistent with the findings of previous studies conducted by Neuert \& Hoeckel (2013), and Hou \& Liu (2014) also provide the same evidence, where personality has a positive impact on decision making effectiveness.

Moreover, this study finds that leadership capability has significantly effected on decision making effectiveness where is at about .197 as its estimated coefficient, and the Pvalue of $.046(<.05)$. It means that the better the capability of leaderships, the more effective the decision made. This finding is in line with Madi et al. (2018), and Yohannes at al. (2015).

\section{Indirect Effect Testing}

Indirect effect is employed to test the hypothesis of leadership capability as mediator among the direct relationships having been addressed in the previous section.

The following figure presents the results of indirect effect testing that explains the role of leadership capability among the relationships. 


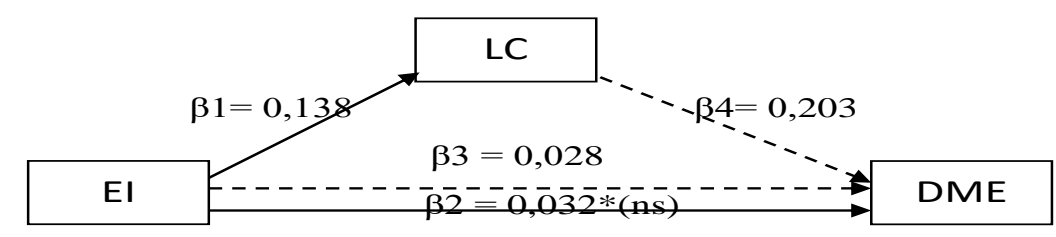

$\begin{array}{lllll}\mathrm{LC}=0,138 \mathrm{EI} & \longrightarrow & \mathrm{R}^{2}=0,049 & \mathrm{~F}= & 6,239 \\ \mathrm{DME}=0,028 \mathrm{EI} & \longrightarrow & \mathrm{R}^{2}=0,019 & \mathrm{~F}= & 3,868 \\ \mathrm{DME}=0,203 \mathrm{LC}+0,138 \mathrm{EI} & \longrightarrow & \mathrm{R}^{2}=0,030 & \mathrm{~F}= & 5,105 \\ \mathrm{P}<.05 & \longrightarrow & \end{array}$

Figure 4. Indirect Effect of Leadership Capability between Emotional Intelligence and Decision Making Effectiveness

Note:

$\begin{array}{lll}\text { EI } & = & \text { Emotional Intelligence } \\ \text { LC } & = & \text { Leadership Capability } \\ \text { DME } & & =\quad \text { Decision Making Effectiveness }\end{array}$

Based on the above figure, and related to the method of Baron and Kenny (1986), it indicates that $\beta 1=0.138, p<.0 .05 ; \beta 2=0.032, p>0.05 ; \beta 3=0.028, p>0.05$, and $\beta 4=0.203, p$ $<0.05$. This means that the variable "leadership capability" has a role as fully mediated between the independent variable "emotional intelligence" and the dependent variable "decision-making effectiveness".

The description above concludes that the hypothesis $\left(\mathrm{H}_{6}\right)$ which suspects that there is an indirect effect of the emotional intelligence variable positively and significantly on the effectiveness of decision making mediated by leadership capabilities is acceptable (not rejected).

Figure 5 below will explain the relationship between "personality" as the independent variable and "decision-making effectiveness" as the dependent variable. Then, this figure will also discuss the influence of the mediating variable (leadership capability) between these relationships.

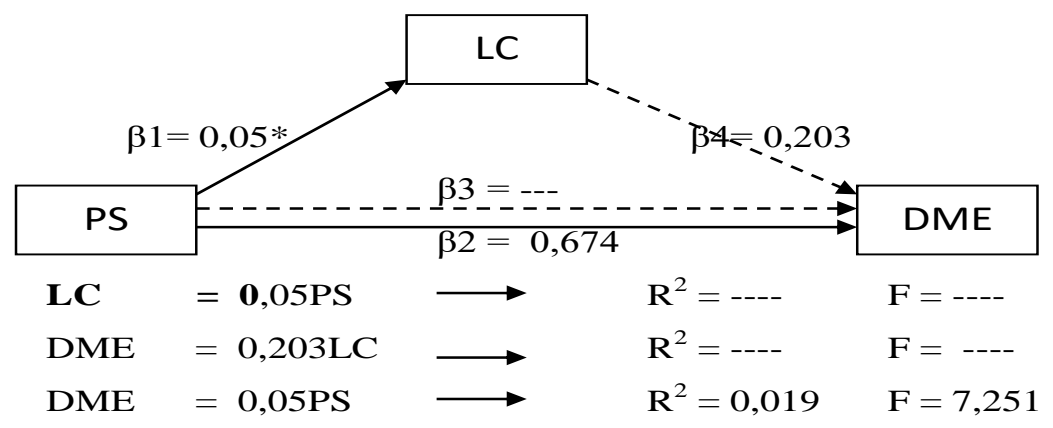

$\mathrm{P}<.05$

$\mathrm{P} *>.05$

Figure 5. Indirect Effect of Leadership Capability between Emotional Intelligence and Decision Making Effectiveness 
Note:

$\begin{array}{lll}\text { PS } & = & \text { Personality } \\ \text { LC } & = & \text { Leadership Capability } \\ \text { DME } & & =\quad \text { Decision Making Effectiveness }\end{array}$

Based on the results of hierarchical regression analysis, it identifies that there is no positive and significant relationship between personality variables and leadership capabilities, which is described by $\beta 1=0.05^{*}$, and $p>0.05$. Furthermore, there is a significant relationship between personality variables and the effectiveness of decision making. This is evidenced by $\beta 2=0.674$, and $p<0.05$. Due to the relationship between the independent variables and the mediation is not significant, and if it is related to the method of Baron and Kenny's (1986) point of view, it cannot be identified the mediating effect. Therefore, it can be concluded that there is no mediating effect of leadership capabilities on the relationship between personality variables and the effectiveness of decision making. This shows that these results do not support the hypothesis $\left(\mathrm{H}_{7}\right)$ which states that there is a positive and significant indirect effect of personality on the effectiveness of decision making mediated by leadership capabilities. In other words, the hypothesis $\left(\mathrm{H}_{7}\right)$ must be rejected.

The above analysis indicates that, from 7 hypotheses in this study, there are 4 of them being not rejected, and the rest is not accepted. For more detail, the description of the accepted or rejected hypotheses in this study can be seen as in the following table.

Table 3. Summary of Hypotheses Testing

\begin{tabular}{|c|l|c|}
\hline & \multicolumn{1}{|c|}{ Hypotheses } & Conclusion \\
\hline $\mathbf{H}_{\mathbf{1}}$ & $\begin{array}{l}\text { Emotional intelligence has a positive influence on capability } \\
\text { leadership. }\end{array}$ & Not Rejected \\
\hline $\mathbf{H}_{\mathbf{2}}$ & Personality has a positive influence on capability leadership. & Not Accepted \\
\hline $\mathbf{H}_{\mathbf{3}}$ & $\begin{array}{l}\text { Emotional intelligence has a positive influence on decision } \\
\text { making effectiveness. }\end{array}$ & Not Accepted \\
\hline $\mathbf{H}_{\mathbf{4}}$ & $\begin{array}{l}\text { Personality has a positive influence on decision making } \\
\text { effectiveness. }\end{array}$ & Not Rejected \\
\hline $\mathbf{H}_{\mathbf{5}}$ & $\begin{array}{l}\text { Leadership capability has a positive influence on decision } \\
\text { making effectiveness. }\end{array}$ & Not Rejected \\
\hline $\mathbf{H}_{\mathbf{6}}$ & $\begin{array}{l}\text { Indirect effect of emotional intelligence on decision making } \\
\text { effectiveness through leadership capability }\end{array}$ & Not Rejected \\
\hline $\mathbf{H}_{\mathbf{7}}$ & $\begin{array}{l}\text { Indirect effect of personality on decision making } \\
\text { effectiveness through leadership capability }\end{array}$ & Not Accepted \\
\hline
\end{tabular}

Source: Data Analysis, 2020 
The final model of this study is as presenting in the following figure:

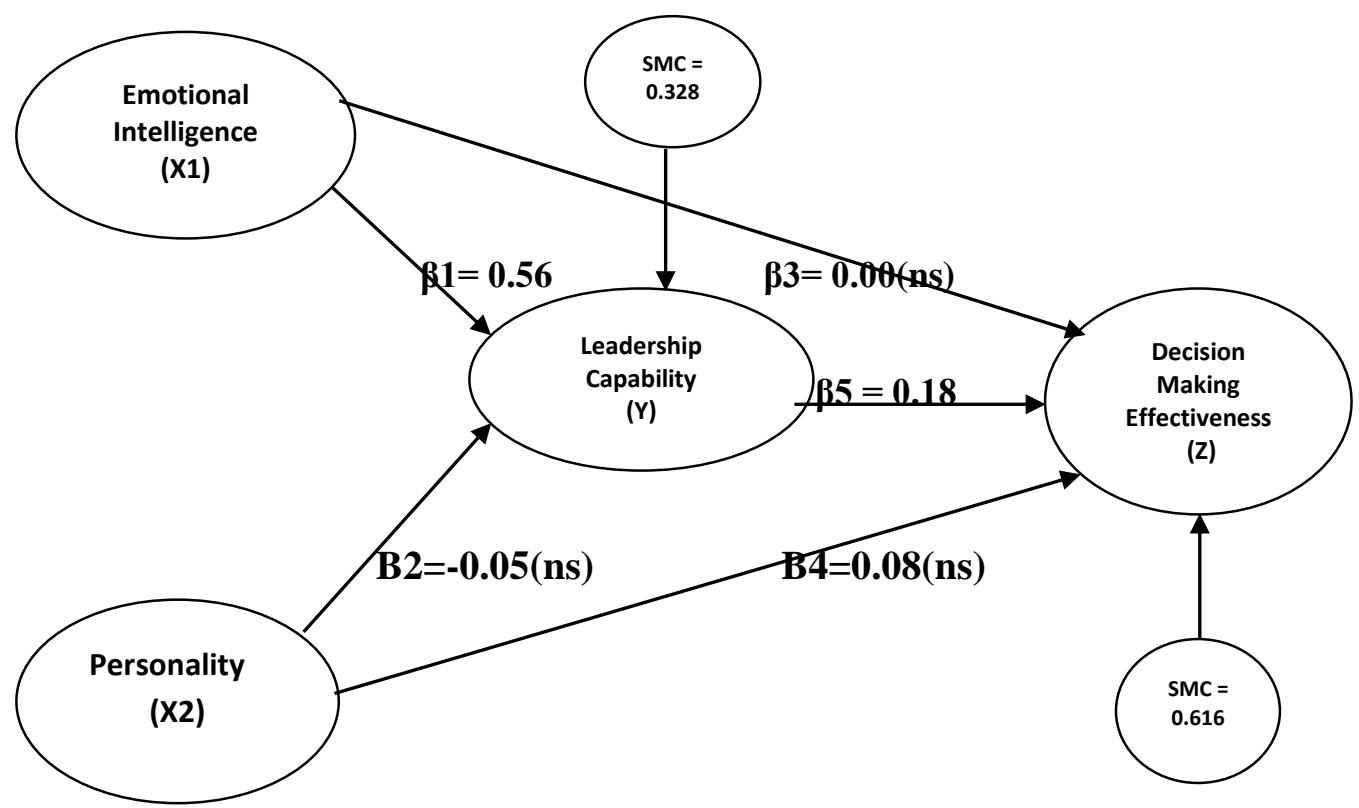

$\mathrm{p}<.05$

ns $=$ not significant

Figure 5. The Final Model of Study

\section{Discussion}

The emotional intelligence has a positive and significant effect on the leadership capability. This finding supports the opinion discovered by Ng \& Feldman (2009) which states that the capability leadership has an important contribution in improving capability leadership. This finding also strengthens the research results of Cavazotte et al. (2012), and Gewertz (2006) who also proves that there is a positive and significant influence of the emotional intelligence on leadership capability.

Furthermore, when related to decision making effectiveness, the results of the analysis show that there is no positive and significant relationship between emotional intelligence and decision making effectiveness. This means that increasing on emotional intelligence will not have a positive impact on improving decision making effectiveness at the Aceh Syariah Bank. This finding is not in line with Hess \& Bacigalupo (2013); and Hou \& Liu (2014) who found that there was an influence of emotional intelligence on decision making effectiveness.

However, there is indirect effect significantly of the variables mediated by leadership capability. The variable plays a role as a fully mediator in this research model in terms of increasing decision making effectiveness caused by emotional intelligence. These findings are similar to the viewpoint of Al-Azzam (2015); and Ejimabo (2015).

Moreover, personality is proven to not have a positively and significantly relationship with leadership capability, and decision making effectiveness. This condition means that the better personality does not affect the increasing leadership capability, and decision making effectiveness. These findings are not in line with Neuert \& Hoeckel (2013); and Conger (2004). 


\section{Conclusion and Recommendation}

Emotional intelligence has a positively and significantly effect on capability leadership. Increased emotional intelligence has an impact on improving capability leadership. Conversely, a decrease in emotional intelligence also significantly reduces capability leadership. However, it does not affect decision making effectiveness directly.

In terms of indirectly relationship, the capability leadership mediates the effect of emotional intelligence on decision making effectiveness. In other words, the influence of emotional intelligence on decision making effectiveness is intervened by the leadership capability. The mediating effect caused by the leadership capability on the relationship between emotional intelligence and decision making effectiveness is fully mediating. Conversely, the capability leadership does not mediate the effect of personality on decision making effectiveness. Therefore, the existence of the capability leadership does not interfere with the significant effect of personality on decision making effectiveness. Therefore, this finding indicates that there is no any role of personality in this study.

Referring to the above research findings, it has confirmed to encourage understanding among academicians and practitioners. In other words, this study has provided a contribution to academic strengthening that there is an existence of leadership capability between relationships of emotional intelligence and decision making effectiveness.

The leader of the Aceh Syariah Bank must be able to encourage an increase in emotional intelligence of employees. Efforts to increase emotional intelligence can be implemented by understanding one's strengths and weaknesses, being able to think clearly before acting and always improving performance.

The leaders of the the Aceh Syariah Bank must maintain their capability that has been implemented and attached to everyone. Operationally, increased their capability can be performed through changing and innovation, integrity and adherence to standards, result orientation and feeling of technical mastery. In addition, increasing the decision making effectiveness can be notified through goals achievement, determination of correct alternatives, adequate information, and quantification of objectives.

As the finding indicates that the effect of emotional intelligence on decision making effectiveness can be mediated by the leadership capability; therefore, it results an academic contribution that the leadership capability has an important role as mediating variable.

\section{References}

Al-Azzam, Z. F. (2015). The effects of perceived transformational leadership style and emotional intelligence on enhancing the effectiveness of decision making in public health sector, International Journal of Advanced Research (2015), 3(12), 1665-1682.

Ahmed, M., \& Ahmed, A. B. (2014). The Impact of Indirect Compensation on Capability leadership: An Overview, Public Policy and Administration Research, 4(6), 27-31.

Ali, N. N. K., \& Tang, S. Y. (2016). Does Multiple Leadership Styles Mediated by Job Satisfaction Influence Better Business Performance? Perception of Mnc Employees in Malaysia, SHS Web of Conferences, 23, 2-16.

Al-Tarawneh, H. A. (2012). The main factors beyond decision making, Journal of Management Research, 4(1), 1-23.

Baron, R. M., and Kenny, D. A. (1986), The Moderator-Mediator Variable Distinction in Social Psychological Research: Conceptual, Strategic, and Statistical Considerations, Journal of Personality and Social Psychology, 51(6), 1173-1182.

Bello, M. S. (2014). Impact of Ethical Leadership on Employee Job Performance, International 
Journal of Business and Social Science, 3(11) 228-236.

Cavazotte, F., Moreno, V., \& Hickmann, M. (2012). Effects of leader intelligence, personality and emotional intelligence on transformational leadership and managerial performance, The Leadership Quarterly, 23(3), 443-455.

Conger, J. A. (2004). Developing leadership capability: What's inside the black box?, Academy of management perspectives, 18(3), 136-139.

Degago, E. (2014). A Study on Impact of Psychological Empowerment on Capability leadership in Small and Medium Scale Enterprise Sectors, European Journal of Business and Management, 6(27), 60-71.

Ejimabo, N. O. (2015). An approach to understanding leadership decision making in organization, European Scientific Journal, 11(11).

Fadlallh, A. W. (2014). Impact of Job Satisfaction on Employees Performance an Application on Faculty of Science and Humanity Studies University of Salman Bin Abdul-Aziz-Al Aflaj, International Journal of Innovation and Research in Educational Sciences, 2(1), 26-31.

Gewertz, B. L. (2006). Emotional intelligence: impact on leadership capabilities. Archives of Surgery, 141(8), 812-814.

Guay, R. P., Choi, D., Oh, I. S., Mitchell, M. S., Mount, M. K., \& Shin, K. H. (2016). Why people harm the organization and its members: Relationships among personality, organizational commitment, and workplace deviance. Human Performance, 29(1), 1-15.

Hair, J. F., Anderson, R. E., Tatham, R. L., \& Black, W. C. (2013), Multivariate data analysis, 7/E, Prentice Hall, Pearson Educational International.

Hess, J., \& Bacigalupo, A. (2013). Applying emotional intelligence skills to leadership and decision making in non-profit organizations. Administrative Sciences, 3(4), 202-220.

Hou, C., Wu, L., \& Liu, Z. (2014). Effect of proactive personality and decision-making selfefficacy on career adaptability among Chinese graduates, Social Behavior and Personality: an international journal, 42(6), 903-912.

Kaiser, R. B., \& Hogan, J. (2011). Personality, leader behavior, and overdoing it, Consulting Psychology Journal: Practice and Research, 63(4), 219.

Knight, A. P. (2014). Positive Is Usually Good, Negative Is Not Always Bad: The Effects of Group Affect on Social Integration and Task Performance. Organization Science. Advance online publication.http://dx.doi.org/10.1287/orsc.2013.0866 (12)

Labbaf. (2011). The Impact of the Emotional Intelligence on Dimensions of Learning Organization: The Case of Isfahan University, 3(5).

Luthans, Fred. (2015). Organizational Behavior (7 $7^{\text {th }}$ ed.). McGraw-Hill, Inc.

Madi, S. A., El Talla, S. A., Abu-Naser, S. S., \& Al Shobaki, M. J. (2018). The dominant pattern of leadership and Its Relation to the Extent of Participation of Administrative Staff in Decision-Making in Palestinian Universities.

Mahdani, F., \& Adam, M. (2017). Pengaruh Motivasi, Kecerdasan Emosional dan Keadilan Organisasi Terhadap Kapabilitas kepemimpinan serta Implikasinya pada Efektifitas pengambilan keputusan (Studi Pada Kanwil PT. Bank Rakyat Indonesia (Persero) Tbk. Banda Aceh). Jurnal Magister Manajemen, 1(1), 1-15.

Maulidar, S. M., \& Yunus, M. (2012). Pengaruh Kepemimpinan Dan Kapabilitas kepemimpinan Terhadap Motivasi Kerja Dan Dampaknya Terhadap Produktivitas Kerja Pegawai Dinas Perindustrian Perdagangan Koperasi Dan Usaha Kecil Menengah Aceh. Jurnal IImu Manajemen, 1(1), 1-20.

Musnadi, S., \& Majid, M. S. A. (2018). Pengaruh motivasi kerja, lingkungan kerja, dan budaya organisasi terhadap efektifitas pengambilan keputusan dan dampaknya pada kinerja 
Bank Aceh Syariah di Kota Banda Aceh. Jurnal Magister Manajemen, 2(1), 115-122.

Mohiuddin, Z. A. (2017). Influence of Leadership Style on Employees performance: Evidence from Literatures, Journal of Marketing and Management, 8(1), 18-30.

Neuert, J., \& Hoeckel, C. A. (2013). The impact of personality traits and problem structures on management decision-making outcomes, Journal of Modern Accounting and Auditing, 9(3), 380.

Ng, K. Y., Ang, S., \& Chan, K. Y. (2008). Personality and leader effectiveness: A moderated mediation model of leadership self-efficacy, job demands, and job autonomy, Journal of Applied Psychology, 93(4), 733.

Palmer, B., Walls, M., Burgess, Z., \& Stough, C. (2001). Emotional intelligence and effective leadership. Leadership \& Organization Development Journal.

Shahzadi, I., Javed, A., Pirzada, S. S., Nasreen, S., \& Khanam, F. (2014). Impact of Employee Motivation on Capability leadership, European Journal of Business and Management, 6(23), 159-166.

Situmeang, R. R. (2017). Pengaruh pengawasan dan pengalaman kerja terhadap kinerja karyawan pada PT. Mitra Karya Anugrah, Asian Journal of Innovation and Entrepreneurship, 2(2), 148-160.

Sulistiyani, A. T. (2012). Modul Pemberdayaan Masyarakat. Modul Kuliah Pemberdayaan Masyarakat, Manajemen dan Kebijakan Publik pada Jurusan Manajemen dan Kebijakan Publik, Fisipol, Universitas Gadjah Mada, Yogyakarta. Modul Tidak Diterbitkan.

Srivastava, A. K. (2008). Effect of Perceived Work Environment on Employees' Job Behaviour and Organizational Effectiveness, Journal of the Indian Academy of Applied Psychology, 34(1), 47-55.

Syamsi, I. (2010). Pengambilan Keputusan dan Sistem Informasi, Cetakan Kedua. Bumi Aksara, Jakarta.

Rahim, M. Y. (2015), Kapabilitas Kepemimpinan pada Universitas Islam Negeri Alauddin Makassar. Jurnal IImu Tarbiyah dan Keguruan, 18(2).

Syamsidar, E., \& Hasyim, S. B. (2018). Pengaruh pengawasan terhadap kinerja pegawai di kantor sub unit rumah perlindungan sosial asuhan anak (RPSAA) Cisurupan - Garut, Jurnal Pembangunan dan Kebijakan Publik, 9(1), 12-20.

Rehman, R. R., \& Waheed, A. (2012). Transformational leadership style as predictor of a decision making styles: Moderatig role of emotional intelligence, Pakistan Journal of Commerce and Social Sciences (PJCSS), 6(2), 257-268.

Robbins, S. P., Dan Coulter, M. (2012). Management, 11th Edition. (New Jersey: Person Education, Inc.

Thaib, E. N. (2013). Hubungan Antara prestasi belajar dengan kecerdasan emosional, Jurnal IImiah Didaktika: Media IImiah Pendidikan dan Pengajaran, 13(2).

Uddin, M. J., Luva, R. H., \& Hossian, S. M. M. (2013). Impact of Organizational Culture on Capability leadership and Productivity: A Case Study of Telecommunication Sector in Bangladesh, International Journal of Business and Management, 8(2), 63-77.

Yantiek, E. (2014). Kecerdasan emosi, kecerdasan spiritual dan perilaku prososial remaja. Persona: Jurnal Psikologi Indonesia, 3(01). 